\title{
JUURNAL.RU
}

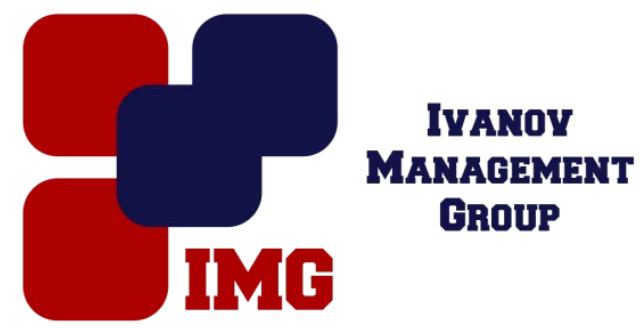

Орешенко Т.Г. Сибирский государственный аэрокосмический университет имени академика М. Ф. Решетневапри Президенте РФ Красноярск, Россия

doi: 10.18411/lj-31-10-2016-2-09

idsp 000001:lj-31-10-2016-2-09

\section{Повышение качества подготовки инженеров в сфере изготовления и испытаний систем управления}

\section{Аннотация}

В статье рассматривается необходимость разработки профессионального стандарта инженера-технолога, инженера-испытателя систем управления ракетной техникой.

Ключевые слова: профессиональный стандарт, трудовые функции, знания, умения

Одним из приоритетных направлений развития производства ракетнокосмической техники является совершенствование технологического потенциала отрасли, реструктуризация, а также обеспечение высоких темпов развития, что позволит сменить «догоняющее» развитие опережающим [1]. Для достижения данной цели, прежде всего, необходимо непрерывно повышать качество подготовки специалистов в условиях все возрастающих требований к квалификации, усложнения и совершенствования выпускаемой продукции. Интенсивное развитие и непрерывное совершенствование аппаратуры, предназначенной для управления ракетно-космической техникой, проведения ее испытаний, ставит задачей пересмотр существующих подходов к высшему образованию. Немалую роль в разрешении данной проблемы играет разработка профессиональных стандартов по ключевым направлениям деятельности, расширяющего возможности управления качеством подготовки. 
Однако, на сегодняшний день профессионального стандарта, в котором были бы закреплены знания, умения и навыки, которыми должны обладать инженеры-конструкторы, инженеры-технологи и инженеры-испытатели в сфере изготовления и испытаний систем управления ракетно-космической техники, не существует, хоть и реалии диктуют необходимость их создания. Кроме того, создание национальной системы квалификаций в России является общенациональной задачей [2]. Так, разработка стандарта позволила бы учесть специфику работы инженеров-конструкторов, инженеров-технологов и инженеров-испытателей систем управления ракетно-космической техникой различных квалификационных уровней. А в процессе разработки экспертами, специалистами по управлению и развитию персонала, работникамипредставителями организаций отрасли были бы сформулированы квалификационные требования, предъявляемые к специалистам, создав, тем самым, эффективный инструмент управления качеством подготовки и оценки текущей деятельности специалистов [3,4]. В ходе работ по созданию стандарта можно опираться на предшествующий опыт разработки, основанный на методологии функционального анализа [5], практическое применение которого описано в [1].

Новый документ должен обеспечить единство требований к содержанию и качеству деятельности инженеров по конструкторскому, технологическому сопровождению изготовления и испытаний систем управления летательными аппаратами, разработку средств оценивания квалификации работников и выпускников высших учебных заведений по данному направлению, формированию государственных образовательных стандартов и программ образования, совершенствование систем мотивации и стимулирования профессионального развития, планирования карьеры. Именно такая задача стоит перед разработчиками профессионального стандарта инженера-конструктора, инженера-технолога, инженера-испытателя систем управления ракетной техникой. 


\section{Литература}

1. Перспективы развития ракетно-космического комплекса России [Электронный ресурс]. URL: http://protown.ru/information/hide/4493.html (дата обращения 13.09.2016).

2. Особенности разработки профессиональных стандартов в сфере услуг / О.Г. Мухамеджанова, Т.И. Зворыкина, А.С. Ермаков // Вестник ассоциации вузов туризма и сервиса. 2013. №1. С. 15-20.

3. Методика разработки профессиональных стандартов / В надзаг.: Российский союз промышленников и предпринимателей. Национальное агентство развития квалификаций. - СПб., 2008. - 29с.

4. Методические рекомендации по разработке профессиональных стандартов (утверждены приказом Министерства труда и социальной защиты Российской Федерации от 29 апреля 2013 года, №170н.

5. Зворыкина Т.И., Мухамеджанова О.Г. Модель оценки и сертификации профессиональной квалификации в сфере туризма и сервиса // Журнал «Стандарты и качество». 2012. №3. С. 68-72. 